\title{
Realistics Mathematics Education Model To Improve Mathematics Learning Outcomes With Fraction Materials In Grade II
}

\author{
Arum Haryanti \\ Universitas Sebelas Maret \\ haryantiarum6@gmail.com
}

\section{Article History}

received 30/4/2021

revised 30/5/2021

accepted 30/6/2021

\begin{abstract}
The aims of this research are to implement the Realistic Mathematics Education model, improve the students' mathematics outcomes, and identify the obstacles and solutions in implementing the Realistic Mathematics Education model in a mathematics class. The method of this study is classroom action research. To gain those reaserch purposes, the researcher conducted this research in two cycles, each cycle consists of planning, implementation, observation, and reflection. The subjects of this study were the second grade students of SDN Ambalkebrek. The results of this study show that this study model could improve the students' mathematics outcomes about fractions materials. It could be seen from the percentage of the students learning outcomes, in the first cycle the percentage was $74.33 \%$ and $83.33 \%$ in cycle II. The obstacles found by the researcher through this research were some students had difficulty in making text questions, not confident in expressing their opinions, and passive in answering the questions. However, the researcher provides some solutions to solve the students' problems, those are guide the students who are struggle, motivate the students, and guide the students to answer questions.
\end{abstract}

Keywords: Realistic Mathematics Education, learning outcomes, mathematics

\section{Abstrak}

Penelitian dilakukan untuk menerapkan langkah model Realistic Mathematics Education, meningkatkan hasil belajar matematika, dan mengidentifikasi kendala serta solusi penerapan model dalam pembelajaran. Penelitian ini merupakan penelitian tindakan kelas yang dilakukan dalam dua siklus yang terdiri dari tahap perencanaan, pelaksanaan, observasi, dan refleksi. Subjek penelitian ini adalah peserta didik kelas II SDN Ambal kebrek. Hasil penelitian menunjukkan bahwa model ini dapat meningkatkan hasil belajar matematika tentang pecahan di kelas II SDN Ambalkebrek tahun pelajaran 2020/2021 yang dibuktikan dengan persentase ketuntasan hasil belajar pada siklus I sebesar $74,33 \%$ menjadi $83,33 \%$ pada siklus II. Kendala yang ditemui yaitu kesulitan membuat soal cerita, malu menyampaikan pendapat, dan kurang aktif saat menjawab pertanyaan. Solusi yang diterapkan yaitu membimbing peserta didik yang kesulitan, memberikan penguatan positif, serta memandu peserta didik untuk menjawab pertanyaan.

Kata kunci: Realistic Mathematics Education, hasil belajar, matematika 


\section{PENDAHULUAN}

Pendidikan di Indonesia saat ini sedang terpuruk dengan adanya pandemi Covid-19. Dampak dari pandemi ini sangat besar dalam bidang pendidikan. Sekolah telah ditutup sejak Maret 2019 mulai dari jenjang pendidikan dasar, pendidikan menengah, sampai pendidikan tinggi. Dengan kondisi demikian, peserta didik diharuskan belajar dari rumah dengan bimbingan guru dan orang tua. Pembelajaran jarak jauh yang selama ini dilakukan membawa dampak positif dan dampak negatif terhadap kegiatan pembelajaran. Dampak positif yang dapat dilihat yaitu peserta didik dapat mandiri dalam mengeksplorasi teknologi dalam pembelajaran. Sedangkan dampak negatif yang paling mencolok yaitu penurunan hasil belajar peserta didik. Penurunan capaian hasil belajar peserta didik terutama di SD Negeri Ambalkebrek terjadi hampir di semua mata pelajaran, termasuk mata pelajaran matematika. Penurunan hasil belajar matematika ini terlihat di semua jenjang kelas, termasuk di kelas II.

Matematika merupakan ilmu yang dapat menambah kemampuan berpikir, bertukar pendapat, serta penyelesaian masalah dalam kehidupan sehari-hari (Susanto, 2013: 185). Pembelajaran matematika di SD dilakukan dengan berfokus pada pengalaman pemecahan masalah yang ada di lingkungan sekitar peserta didik. Mata pelajaran matematika di kelas II terintegrasi dengan mata pelajaran bahasa Indonesia dan SBdP.

Berdasarkan observasi awal diketahui bahwa pembelajaran matematika yang dilakukan belum memacu keaktifan peserta didik serta adanya ketidaktertarikan peserta didik terhadap pembelajaran matematika karena dianggap sulit. Permasalahan yang ditemukan sesuai dengan pendapat Zakaria \& Syamaun (2017: 34) yang mengemukakan bahwa matematika dianggap mata pelajaran yang sulit dan sangat membosankan bagi peserta didik. Kondisi tersebut berdampak pada ketuntasan hasil belajar matematika pada Penilaian Tengah Semester (PTS) genap yang baru mencapai $27 \%$ dengan nilai rata-rata 60,96 .

Dari uraian permasalahan tersebut, maka pembelajaran matematika yang dilakukan perlu diadakan perbaikan. Pembelajaran matematika akan lebih bermakna jika ditunjang dengan aktivitas langsung peserta didik dalam menemukan konsep yang dipelajari. Menurut Hasibuan, dkk. (2019:34) salah satu model pembelajaran yang ditunjang dengan penekanan konteks nyata yang dikenal peserta didik dan dilakukan konstruksi pengetahuan matematika oleh peserta didik adalah model Realistic Mathematics Education. Menurut Freudenthal (Sumirattana, dkk., 2017: 209) model Realistic Mathematics Education merupakan model pembelajaran yang menggunakan dunia nyata sebagai sumber atau titik awal pengembangan konsep matematika. Langkah model Realistic Mathematics Education menurut Wahyudi (2015:32-33) dan Shoimin (2014:150) meliputi memahami masalah/konteks, menjelaskan masalah kontekstual, menyelesaikan masalah kontekstual, membandingkan dan mendiskusikan jawaban, serta menyimpulkan.

Pembelajaran matematika abad 21 ini menuntut pengembangan kemampuan HOTS dalam memecahkan segala permasalahan dalam kehidupan sehari-hari. Hal tersebut tertuang dalam tuntutan kurikulum 2013 dengan adanya anjuran untuk menerapkan pembelajaran yang kontekstual dan sesuai dengan pengalaman serta lingkungan peserta didik. Pada kurikulum 2013, pembelajaran matematika di kelas II yang terintegrasi dengan muatan pelajaran bahasa Indonesia dan SBdP banyak menekankan pada kegiatan eksplorasi lingkungan belajar peserta didik dalam kegiatan pembelajaran. Cakupan materi yang akan digunakan dalam penelitian ini merupakan salah satu KD pada buku guru tema 7 (Kebersamaan) karangan Purnomosidi (2017) yaitu KD 3.7 Menjelaskan pecahan $\frac{1}{2}, \frac{1}{3}$, dan $\frac{1}{4}$ menggunakan benda-benda konkret dalam kehidupan sehari-hari. 
Hasil belajar merupakan tingkat keberhasilan dari peserta didik meliputi aspek pengetahuan, sikap, dan keterampilan yang dinyatakan dalam skor setelah melakukan kegiatan pembelajaran. Hasil belajar peserta didik kelas II SDN Ambalkebrek diukur dengan hasil tes setelah kegiatan pembelajaran matematika. Adapun tingkatan pengetahuan yang digunakan dalam penelitian ini meliputi tingkatan memahami (C2), menganalisis (C4), dan mencipta (C6).

Berdasarkan uraian di atas, peneliti melakukan penelitian dengan tujuan (1) mendeskripsikan langkah penggunaan model Realistic Mathematics Education untuk meningkatkan hasil belajar matematika tentang pecahan, (2) meningkatkan hasil belajar matematika tentang pecahan, serta (3) mendeskripsikan kendala dan solusi penggunaan model Realistic Mathematics Education dalam peningkatan hasil belajar matematika tentang pecahan.

\section{METODE}

Penelitian yang dilakukan adalah penelitian tindakan kelas. Subjek dalam penelitian yaitu peserta didik kelas II yang berjumlah 26 peserta didik. Data pada penelitian ini meliputi data kualitatif berupa penerapan model Realistic Mathematics Education dalam pembelajaran dan data kuantitatif berupa hasil belajar matematika peserta didik tentang pecahan. Data penelitian ini bersumber dari peserta didik kelas II dengan teknik pengumpulan data menggunakan tes, observasi, dan wawancara. Uji validitas data dengan triangulasi teknik dan triangulasi sumber. Analisis data penelitian meliputiu reduksi data, penyajian data, dan penarikan kesimpulan.

Indikator kinerja penelitian ini adalah pelaksanaan langkah pembelajaran menggunakan model Realistic Mathematics Education dan ketuntasan hasil belajar matematika dengan ketercapaian $85 \%$. Prosedur penelitian meliputi tahap perencanaan, pelaksanaan, pengamatan, dan refleksi.

\section{HASIL DAN PEMBAHASAN}

Penggunaan model Realistic Mathematics Education dalam pembelajaran matematika meliputi langkah-langkah: (1) memahami masalah/konteks, (2) menjelaskan masalah kontekstual, (3) menyelesaikan masalah kontekstual, (4) membandingkan dan mendiskusikan jawaban, serta (5) menyimpulkan. Langkah pembelajaran yang digunakan dalam penelitian ini mengacu pada langkah-langkah yang dikemukakan oleh Shoimin (2012:150) dan Wahyudi (2015: 32-33) yang disimpulkan menjadi langkah yang telah diuraiukan di atas.

Pembelajaran dengan penggunaan model Realistic Mathematics Education diamati oleh peneliti berdasarkan lembar observasi terhadap peserta didik. Hasil observasi pada siklus I dan siklus II ditampilkan pada tabel berikut.

Tabel 1. Analisis Hasil Observasi Penggunaan Model Realistic Mathematics Education

\begin{tabular}{llcc}
\hline \multicolumn{1}{c}{ Sumber Data } & & \multicolumn{2}{c}{ Siklus } \\
\cline { 3 - 4 } & & I & II \\
\hline Guru & Persentase (\%) & 79,44 & 85,56 \\
Peserta didik & Persentase (\%) & 80,56 & 86,11 \\
\hline
\end{tabular}

Berdasarkan tabel di atas, dapat disimpulkan bahwa proses pembelajaran siklus I dan siklus II mengalami kenaikan yang signifikan. Hasil observasi capaian guru pada siklus I yaitu 79,44\% mengalami kenaikan pada siklus II yaitu sebesar $85,56 \%$. Hasil observasi terhadap capaian peserta didik pada siklus I sebesar $80,56 \%$ mengalami kenaikan pada siklus II yaitu $86,11 \%$. 
Data hasil belajar peserta didik diperoleh dari hasil evaluasi setelah kegiatan pembelajaran pada siklus I dan siklus II. Hasil evaluasi yang diperoleh ditampilkan pada tabel berikut.

Tabel 2. Analisis Hasil Belajar Peserta Didik Siklus I dan Siklus II

\begin{tabular}{lcccccc}
\hline \multicolumn{1}{c}{ Aspek } & Pert. & Siklus I & \multicolumn{3}{c}{ Siklus II } \\
& Pert. & Pert. & Pert. & Pert. & Pert. \\
& $\mathbf{1}$ & $\mathbf{2}$ & $\mathbf{3}$ & $\mathbf{1}$ & $\mathbf{2}$ & $\mathbf{3}$ \\
\hline Tuntas (\%) & 65 & 77 & 81 & 77 & 85 & 88 \\
Belum Tuntas (\%) & 35 & 23 & 19 & 23 & 15 & 12 \\
Rata-rata & 75,19 & 73,27 & 76,92 & 72,69 & 75,00 & 79,42 \\
\hline
\end{tabular}

Berdasarkan tabel di atas, dapat diambil kesimpulan bahwa rata-rata ketuntasan hasil belajar peserta didik mengalami kenaikan pada siklus I sebesar $74,33 \%$ dan siklus II sebesar $83,33 \%$. Ketuntasan hasil belajar pada siklus II telah mencapai indikator kinerja penelitian yang ditentukan yaitu $85 \%(\mathrm{KKM}=70)$. Berdasarkan hasil evaluasi, dapat disimpulkan bahwa kesulitan sebagian peserta didik pada siklus I yaitu soal jenjang C2, C4, dan penulisan soal cerita secara lengkap. Kendala tersebut telah dapat diatasi pada siklus II.

Pada siklus I guru banyak mengalami kendala pada langkah membandingkan dan mendiskusikan jawaban. Sedangkan pada siklus II kendala yang dialami guru yaitu dalam pengaturan waktu pembelajaran dikarenakan adanya pandemi sehingga pembelajaran berlangsung dalam kelompok-kelompok kecil. Pada siklus I peserta didik juga banyak terkendala pada langkah keempat yaitu membandingkan dan mendiskusikan jawaban. Sedangkan pada siklus II kendala yang muncul hanya kesulitan saat pembuatan soal cerita menggunakan bahasa yang baku dan runtut.

Pada langkah ini memahami masalah/konteks, peserta didik diberikan masalah kontekstual untuk dipahami oleh peserta didik. Masalah yang diberikan harus masalah yang dekat dengan kehidupan anak agar mudah dicerna oleh peserta didik saat pembelajaran. Hal tersebut sesuai dengan pendapat Shoimin (2014: 150) bahwa langkah ini menekankan pada pengenalan ragam benda ataupun kejadian yang biasa ditemui di lingkungan peserta didik.

Pada langkah menjelaskan masalah kontekstual, peserta didik diberi penjelasan mengenai situasi dan kondisi masalah kontekstual. Guru memberikan penjelasan seperlunya terhadap bagian tertentu serta membangun interaksi peserta didik dan guru dalam pembelajaran. Pada langkah ketiga yaitu menyelesaikan masalah kontekstual, peserta didik menyelesaikan masalah menggunakan lembar kegiatan. Guru memotivasi peserta didik untuk menyelesaikan masalah dengan cara mereka sendiri.

Dalam langkah membandingkan dan mendiskusikan jawaban menggunakan kontribusi dan interaksi antar peserta didik dalam pembelajaran. Guru memfasilitasi dan memberikan waktu bagi peserta didik untuk membandingkan serta mendiskusikan jawaban secara berkelompok. Berdasarkan hasil diskusi, guru mengarahkan peserta didik untuk menarik kesimpulan suatu konsep matematika yang dipelajari. Pada langkah menyimpulkan, guru memastikan peserta didik mampu memahami konsep pecahan yang dipelajari berdasarkan peragaan dan soal cerita yang telah dibuat oleh peserta didik.

Peningkatan hasil belajar matematika peserta didik tentang pecahan diukur menggunakan teknik tes hasil belajar dengan instrument lembar soal evaluasi. Teknik pengumpulan data hasil belajar diterapkan pada setiap pertemuan setelah proses pembelajaran. Aspek yang diukur dalam penelitian yaitu aspek kognitif yang terdiri dari tiga ranah yaitu memahami (C2), menganalisis (C4), dan mencipta (C6) yang diukur 
berdasarkan hasil evaluasi setelah mengikuti pembelajaran dengan model Realistic Mathematics Education pada materi pecahan.

Berdasarkan hasil evalusi peserta didik diketahui bahwa pada ranah kognitif memahami dan menganalisis telah dapat dikuasai dengan baik oleh peserta didik. Selain itu, peserta didik juga telah mampu menuliskan soal cerita secara lengkap. Namun sebagian peserta didik masih kesulitan untuk menuliskan soal cerita dengan bahasa yang baku dan runtut pada jenjang C6.

Penggunaan model Realistic Mathematics Education dalam pembelajaran matematika dapat meningkatkan hasil belajar peserta didik di kelas II SDN Ambalkebrek secara signifikan. Hal ini sesuai dengan hasil penelitian yang dilakukan oleh Umar, dkk. (2020: 250) serta Mbagho \& Tupen (2021:121) yang membuktikan bahwa model Realistic Mathematics Education dapat meningkatkan hasil belajar matematika secara signifikan. Pada hasil Penilaian Tengah Semester (PTS) genap tahun pelajaran 2020/2021 terdapat 19 dari 26 peserta didik yang belum mencapai KKM dengan persentase ketuntasan hasil belajar hanya $27 \%$. Setelah dilakukan tindakan, persentase ketuntasan hasil belajar pada siklus I meningkat menjadi $65 \%$ pada pertemuan pertama, $77 \%$ pada pertemuan kedua, dan $81 \%$ pada pertemuan ketiga. Pada siklus II terjadi penurunan ketuntasan pada pertemuan pertama yaitu sebesar $77 \%$, meningkat menjadi $85 \%$ pada pertemuan kedua, dan $88 \%$ pada pertemuan ketiga. Berdasarkan hasil di atas, dapat diketahui bahwa pada siklus I belum mampu mencapai indikator kinerja penelitian yang ditetapkan. Sedangkan pada siklus II pertemuan kedua dan ketiga telah mampu memenuhi indikator kinerja penelitian sehingga pelaksanaan tindakan dapat dihentikan.

Berdasarkan pembahasan hasil di atas tentang hasil belajar peserta didik yang didukung penelitian yang telah dilakukan, dapat disimpulkan bahwa model Realistic Mathematics Education dapat meningkatkan hasil belajar matematika tentang pecahan di kelas II SDN Ambalkebrek tahun pelajaran 2020/2021.

Berdasarkan hasil observasi langkah model Realistic Mathematics Education, ditemukan kendala dalam pembelajaran yaitu (a) terdapat peserta didik yang kesulitan dalam membuat soal cerita, (b) malu saat menyampaikan pendapat dalam kelompok, dan (c) terdapat sebagian peserta didik kurang aktif saat menjawab pertanyaan pemantik guru. Kendala yang ditemui sesuai dengan pendapat Wijaya (Susilowati, 2018: 49) yang mengemukakan bahwa guru tidak mudah dalam mendorong peserta didik menyelesaikan masalah karena adanya perbedaan kemampuan peserta didik. Berdasarkan kendala yang ditemui saat pembelajaran, solusi yang telah diterapkan yaitu: (a) membimbing peserta didik yang kesulitan membuat soal cerita, (b) memberikan berbagai penguatan positif, dan (c) memandu peserta didik dalam menjawab pertanyaan pemantik.

\section{SIMPULAN}

Berdasarkan hasil penelitian dapat disimpulkan bahwa penggunaan model Realistic Mathematics Education dengan langkah-langkah memahami masalah/konteks, menjelaskan masalah kontekstual, menyelesaikian masalah kontekstual, membandingkan dan mendiskusikan jawaban, serta menyimpulkan dapat meningkatkan hasil belajar matematika tentang pecahan di kelas II SDN Ambalkebrek tahun pelajaran 2020/2021 yang dibuktikan dengan persentase ketuntasan hasil belajar pada siklus I sebesar $74,33 \%$ menjadi $83,33 \%$ pada siklus II. Kendala yang ditemui yaitu (a) terdapat peserta didik yang kesulitan dalam membuat soal cerita, (b) malu saat menyampaikan pendapat dalam kelompok, dan (c) terdapat sebagian peserta didik kurang aktif saat menjawab pertanyaan pemantik guru. Adapun solusi yang telah diterapkan yaitu: (a) membimbing peserta didik yang kesulitan membuat soal cerita, (b) memberikan berbagai penguatan positif, dan (c) memandu peserta didik dalam menjawab pertanyaan pemantik. 
Hasil penelitian ini sangat penting untuk direkomendasikan kepada guru kelas sebagai upaya perbaikan dan peningkatan kualitas proses serta hasil belajar di sekolah. Tindak lanjut yang dapat dilakukan oleh guru yaitu mensosialisasikan model Realistic Mathematics Education kepada guru kelas lain dalam kegiatan diklat, KKG, atau pengembangan profesionalitas guru lainnya.

\section{DAFTAR PUSTAKA}

Hasibuan, A.M., dkk. (2019). Development of Learning Materials Based on Realistic Mathematics Education to Improve Problem Solving Ability and Student Learning Independence. International Electronic Journal of Mathematics Education Vol. 14: 243-252.

Mbagho, H.M. \& Tupen, S.N. (2021). Pembelajaran Matematika Realistik dalam Meningkatkan Hasil Belajar Matematika Materi Operasi Bilangan Pecahan. Jurnal Basicedu Vol. 5: 121-132.

Purnomosidi. (2017). Buku Guru Kelas II Tema 7: Kebersamaan Buku Tematik Terpadu Kurikulum 2013. Jakarta: Pusat Kurikulum dan Perbukuan, Badan Penelitian dan Pengembangan Kementrian Pendidikan dan Kebudayaan.

Shoimin. (2014). 68 Model Pembelajaran Inovatif dalam Kurikulum 2013. Yogyakarta: Ar-Ruzz Media.

Sumirattana, S., dkk. (2017). Using Realistic Mathematics Education and the DAPIC Problem-Solving Process to Enhance School Students' Mathematical Literacy. Kasetsart Journal of Social Sciences 38: 307-315.

Susanto, A. (2013). Teori Belajar dan Pembelajaran di Sekolah Dasar. Jakarta: Kencana.

Susilowati, E. (2018). Peningkatan Aktivitas dan Hasil Belajar Matematika Siswa SD melalui Model Realistic Mathematic Education (RME) pada Siswa Kelas IV Semester I di SD Negeri 4 Kradenan Kecamatan Kradenan Kabupaten Grobogan Tahun Pelajaran 2017/2018. Jurnal Pinus Vol. 4: 44-53.

Umar, dkk. (2020). Efektivitas Pendekatan Matematika Realistik Berbasis Etnomatematika Dalam Meningkatkan Hasil Belajar Peserta Didik Sekolah Dasar. Jurnal Didika Wahana IImiah Pendidikan Dasar Vol. 6: 250-260.

Wahyudi. (2015). Panduan Pembelajaran Matematika di Sekolah Dasar. Surakarta: UNS Press.

Zakaria, E. \& Syamaun, M. (2017). The Effect of Realistic Mathematics Education Approach on Students' Achievement And Attitudes Towards Mathematics. Journal Mathematics Education Trends and Research 2017: 32-40. 